\title{
AMNIOTIC SEX CHROMATIN AND FOETAL SEXING IN THE MOUSE
}

\author{
ANNE D. VICKERS \\ Physiological Laboratory, University of Cambridge
}

(Received 18th Fuly 1967)

\begin{abstract}
Summary. Sex chromatin is present in 67 to $90 \%$ of the ectodermal cell nuclei in the female mouse amnion. A similar body is found in 2 to $15 \%$ of these nuclei in the male. This criterion is a reliable indicator of the sex of the foetus from the 11 th day of gestation onwards.
\end{abstract}

Sex chromatin is found in many of the cell nuclei of females, but is absent from the nuclei of males. In a suitable tissue, the presence or absence of nuclear sex chromatin is a reliable indicator of the genetic sex of the individual. The nuclei of mouse cells usually contain so much heterochromatin that sex chromatin cannot be detected (Moore, 1966); nevertheless, sex chromatin should be present in suitable tissues, because the behaviour of the $\mathrm{X}$ chromosomes in the mouse is similar to that of other species. One $\mathrm{X}$ chromosome in each cell of the female mouse is genetically inactive (Lyon 1961), replicates its DNA late in the S-phase of the cell cycle (Galton \& Holt, 1965), and is heterochromatic in the prophase stage of mitosis (Ohno \& Hauschka, 1960). These features are associated with the appearance of sex chromatin in other species and, therefore, provide indirect evidence for sex chromatin formation in the mouse. Kenney \& Mittwoch (1965) found sex chromatin in cultured fibroblasts from female mice, but only in $10 \%$ of 'clear' cells with few chromocentres; these 'clear' cells constituted about half of the total cell population. Bianchi \& de Bianchi (1966) and Farias, Kajii \& Gardner (1967) sexed rat foetuses by observation of sex chromatin in the amnion; Bianchi \& de Bianchi (1966) state, although without further details, that the method can be used in the mouse. The amnion is known to be one of the most favourable tissues for nuclear chromatin analysis: the human female amnion contains 80 to $96 \%$ sex chromatin positive nuclei (Klinger, 1966). It therefore seemed worthwhile to examine the mouse amnion to discover firstly whether sex chromatin was visible, and secondly whether it could be used for sexing foetuses.

Pregnant mice were killed $10 \frac{1}{2}, 11 \frac{1}{2}, 13 \frac{1}{2}$ and $17 \frac{1}{2}$ days after ovulation. The amnion was dissected out, transferred in a pipette to a clean, albumen-coated slide, and flattened with a paintbrush and fine forceps; care was needed in handling the amnion from early foetuses. The amnion was fixed in $95 \%$ alcohol and coated with celloidin (Geneva Conference, 1966), stained for 15 min in 2\% lactic-acetic-orcein, dehydrated and mounted in Canada balsam. 
The sex of the $10 \frac{1}{2}$-, $11 \frac{1}{2}$ - and $13 \frac{1}{2}$-day-old foetuses was established by chromosome analysis of at least ten metaphase plates, obtained from the whole foetus or the foetal liver by the method of Ford \& Woollam (1963). The female karyotype contains two small chromosomes whilst the male karyotype contains three small chromosomes: the $\mathrm{Y}$ plus the two smallest autosomes (Stich \& Hsu, 1960). The preparations of chromosomes and amniotic membranes were coded and studied 'blind'. The sex of the 171-day-old foetuses was established by inspection of the reproductive system.

\section{TABLE 1}

THE PERGENTAGE OF ECTODERMAL GELL NUCLEI WITH SEX GHROMATIN IN THE MOUSE AMNION

\begin{tabular}{c|c|c}
\hline \multirow{2}{*}{$\begin{array}{c}\text { Age of foetus } \\
\text { (days) }\end{array}$} & \multicolumn{2}{|c|}{$\%$ of nuclei with sex chromatin } \\
\cline { 2 - 3 } & Female & \multicolumn{1}{|c}{ Male } \\
\hline $10 \frac{1}{2}$ & $81 \cdot 3 \pm 1 \cdot 4 *$ & $3 \cdot 7 \pm 0 \cdot 6$ \\
$11 \frac{1}{2}$ & $86 \cdot 8 \pm 0 \cdot 6$ & $6 \cdot 8 \pm 0.6$ \\
$13 \frac{1}{2}$ & $77 \cdot 5 \pm 0 \cdot 8$ & $11 \cdot 3 \pm 1 \cdot 2$ \\
$17 \frac{1}{2}$ & $73.5 \pm 1 \cdot 7$ & $8 \cdot 2 \pm 1 \cdot 0$ \\
\hline
\end{tabular}

* S.E. of the mean.

TABLE 2

THE NUMBER OF MOUSE FOETUSES SEXED BY NUGLEAR CHROMATIN AND ALSO BY KARYOTYPE OR MORPHOLOGY

\begin{tabular}{|c|c|c|c|c|c|c|}
\hline \multirow{2}{*}{$\begin{array}{c}\text { Age of foetus } \\
(\text { days })\end{array}$} & \multicolumn{2}{|c|}{$\begin{array}{l}\text { Nuclear } \\
\text { chromatin }\end{array}$} & \multicolumn{2}{|c|}{ Karyotype } & \multicolumn{2}{|c|}{ Morphology } \\
\hline & Female & Male & Female & Male & Female & Male \\
\hline $\begin{array}{c}10 \frac{1}{2} \\
11 \frac{1}{2} \\
13 \frac{1}{2} \\
17 \frac{1}{2} \\
10 \frac{1}{2}-17 \frac{1}{2}\end{array}$ & $\begin{array}{r}6 \\
7 \\
12 \\
14 \\
39\end{array}$ & $\begin{array}{r}9 \\
13 \\
7 \\
17 \\
46\end{array}$ & $\begin{array}{c}6 \\
6^{*} \\
12\end{array}$ & $\begin{array}{c}9 \\
11^{*} \\
6^{*} \\
26\end{array}$ & $\begin{array}{l}14 \\
14\end{array}$ & $\begin{array}{l}17 \\
17\end{array}$ \\
\hline
\end{tabular}

* Some chromosome cultures failed.

Observations of the amnion were made with bright-field and phase-contrast microscopy; the former gave more satisfactory results with the $10 \frac{1}{2}$ - and $11 \frac{1}{2}$ day-old amnion. The mouse amnion was found to consist. of a continuous sheet of flattened ectodermal cells and an equivalent number of scattered mesodermal cells. The mesodermal cell nuclei contained many large chromocentres and no clear sexual dimorphism could be demonstrated. The ectodermal cell nuclei contained only a few small particles of chromatin and also sometimes contained a chromocentre, approximately $1.25 \times 0.9 \mu$ in size, which was morphologically identical with sex chromatin. The amniotic membranes were classified into those with many sex chromatin bodies and those with few sex chromatin bodies; the former were assumed to come from female foetuses and the latter from male foetuses (Plate 1). Detailed counts of 


\section{PLATE 1}

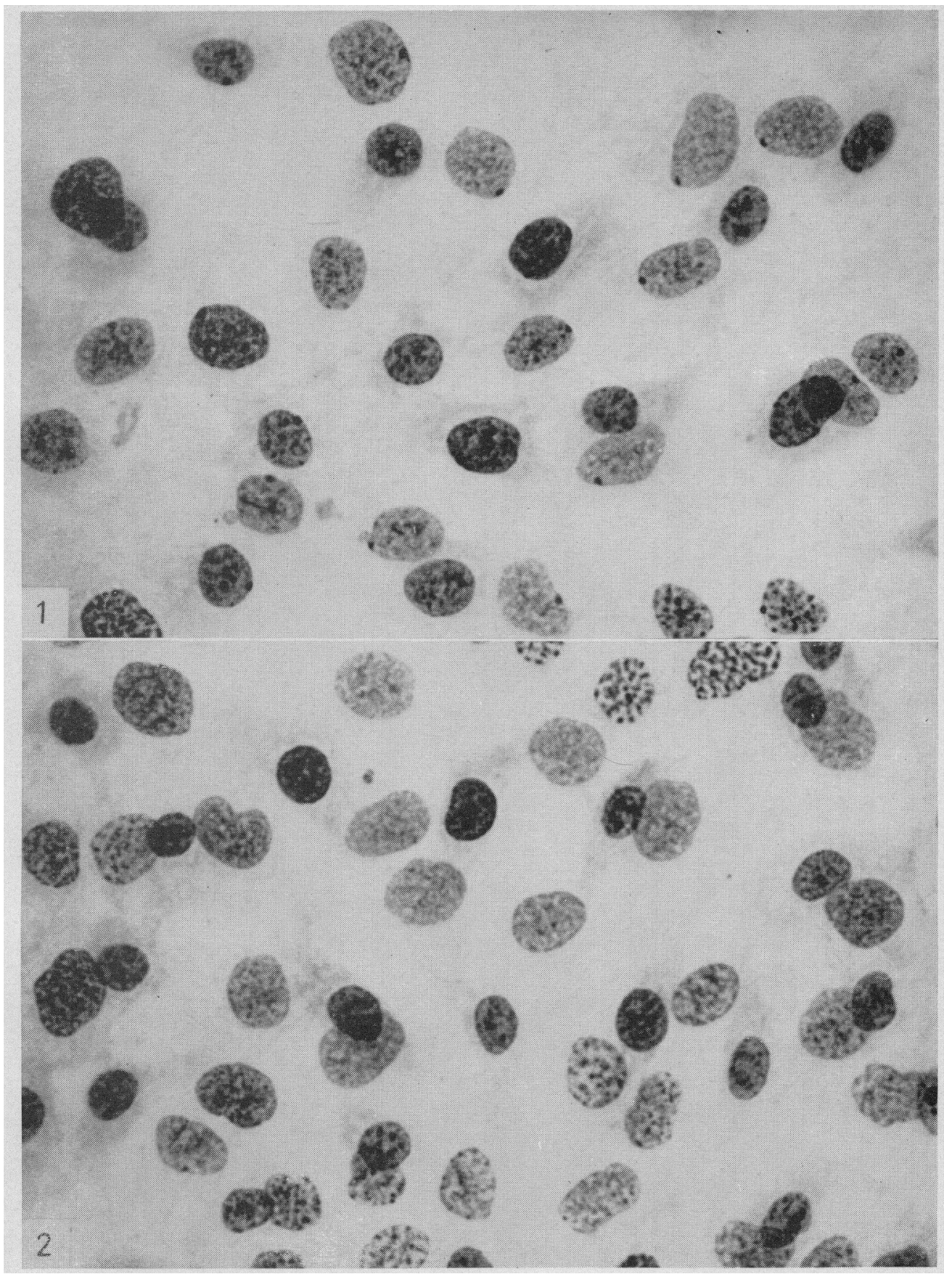

Fig. 1. Amnion of a female mouse foetus, $13 \frac{1}{2}$ days of gestation $(\times 240)$.

FIG. 2. Amnion of a male mouse foetus, $13 \frac{1}{2}$ days of gestation $(\times 240)$. 
sex chromatin were made on a sample of six foetuses of either sex from each age group. One hundred ectodermal cell nuclei from each individual were scored for the presence or absence of a sex chromatin body adjacent to the nuclear membrane and the results are shown in Table 1. Sex chromatin was present in 67 to $90 \%$ of the nuclei of females, whilst a similar body was present in only 2 to $15 \%$ of the nuclei of males.

Eighty-five foetuses were sexed in the experiment, and in every case the sex, as determined by the proportion of cells with sex chromatin in the amnion, was correct as judged by karyotype or morphology (Table 2). There were no errors or doubtful classifications; every foetus handled could be sexed on the basis of the amniotic chromatin, but the chromosome cultures failed in four cases. These results show that the amnion provides excellent material for the demonstration of sex chromatin in the mouse, and can be used for sexing foetuses from the 11 th day of gestation onwards. The amnion from younger foetuses is too small to handle reliably, but it does show sexual dimorphism of nuclear chromatin (unpublished observations).

The existing methods of sexing mouse foetuses are unsatisfactory: the gonads are not clearly differentiated until the 15 th day of gestation and although chromosome analysis can be applied at any age, it is time-consuming and involves destruction of the foetus. The presence of sex chromatin in the mouse amnion provides an alternative method of sexing foetuses which is rapid and reliable and leaves the foetus intact for any other procedures.

I should like to thank Professor A. S. Parkes, Dr R. G. Edwards and Dr T. Vickers for their advice and Miss V. Hunn for able technical assistance. This work was carried out during the tenure of a Medical Research Council grant; working expenses were defrayed by a grant from the Ford Foundation to Professor A. S. Parkes.

\section{REFERENCES}

BIANChI, N. O. \& DE BIANChI, M. S. A. (1966) Technique for investigation of sex chromatin in amniotic membrane of rat foetuses. Nature, Lond. 212, 1593.

Farias, E., KaJII, T. \& Gardner, L. I. (1967) Technique for investigation of sex chromatin in amniotic membrane of rat foetuses. Nature, Lond. 214, 499.

Ford, E. H. R. \& Woollam, D. H. M. (1963) A colchicine, hypotonic citrate, air drying sequence for foetal mammalian chromosomes. Stain Technol. 38, 271.

Galton, M. \& Holt, S. F. (1965) Asynchronous replication of the mouse sex chromosomes. Expl Cell Res. 37, 111.

Geneva Conference (1966) Standardization of procedures for chromosome studies in abortion. Bull. Wld Hlth Org. 34, 765.

KenNey, J. D. \& MrrTwoch, U. (1965) Barr bodies in the mouse. Nature, Lond. 208, 93.

KLINGER, H. P. (1966) Morphological characteristics of the sex chromatin. In: The Sex Chromatin, p. 80. Ed. K. L. Moore. Saunders, London.

Lyon, M. F. (1961) Gene action in the X-chromosome of the mouse (Mus musculus L.). Nature, Lond. $190,372$.

Moore, K. L. (1966) The sex chromatin, p. 40. Saunders, London.

Ohno, S. \& HauschKa, T. S. (1960) Allocycly of the X-chromosome in tumours and normal tissues. Cancer Res. 20, 541 .

Strch, H. F. \& Hsu, T. C. (1960) Cytological identification of male and female somatic cells in the mouse. Expl Cell Res. 20, 248. 